\title{
The Use of Appropriate Communication Channels to Understand Life Threatening Diseases: A Study of Viral Hepatitis Infection among Onikolobo Residents in Abeokuta, Nigeria
}

\author{
Amos Kolawole', Amoo John Kehinde'2, Adegboyega Taofeek Tope ${ }^{3}$, \\ Agu Georgia Chinemenwa ${ }^{4}$, Tejuosho Wasiu ${ }^{1}$ \\ ${ }^{1}$ Department of Mass Communication, Moshood Abiola Polytechnic, Abeokuta, Nigeria \\ ${ }^{2}$ State Hospital, Isara, Nigeria \\ ${ }^{3}$ Department of Biological Sciences, Southwestern University Nigeria, Ijebu, Nigeria \\ ${ }^{4}$ Department of Microbiology, Olabisi Onabanjo University, Ago-Iwoye, Nigeria \\ Email:amoszecha@yahoo.com,amoskehinde2006@yahoo.com,tope.gboyega@yahoo.com, \\ georgiaagu@yahoo.com
}

Received 22 October 2015; accepted 22 December 2015; published 25 December 2015

Copyright (C) 2015 by authors and Scientific Research Publishing Inc.

This work is licensed under the Creative Commons Attribution International License (CC BY).

http://creativecommons.org/licenses/by/4.0/

c) (i) Open Access

\section{Abstract}

This work examines the use of communication channels to sensitize the people about life threatening diseases with special emphasis on Hepatitis. It becomes very topical at this moment because most of the viral infections wreak havoc such as Acquired Immune Deficiency Syndrome (AIDS) and more recently, Ebola Virus Disease (EVD) assumed an epidemic proportion because the people were not adequately sensitized with precautionary measures against them. One of such measures is dissemination of useful information on how to avoid or contain such viral infections. It also concerns itself with hepatitis because of its contagious nature and the way it attacks the liver. The study reviews relevant concepts to information dissemination. It discovers that as deadly as the disease is, most people, including some health attendants in hospitals do not understand what it means and how it is contracted. In addition, it was discovered that $60 \%$ of the total respondents did not know about hepatitis. $73 \%$ of those who claimed they knew about it knew through friends and not through the media. $80 \%$ of those who claimed they sought health information from the media did not know about hepatitis. $65 \%$ of those who claimed they had high access to radio did not really seek health information from the radio. In the communities in Nigeria, we suggest that there should be increased public awareness about viral diseases, complete immunization against viral hepatitis and better sanitation facilities. Other efforts by the Government should in- 
clude the provision of safe drinking water; expansion of well-equipped hospitals among other health developmental programmes will go a long way in the reduction of hepatitis in communities, among pregnant women as well as its associated maternal effects in the communities.

\title{
Keywords
}

\author{
Communication, Hepatitis, Onikolobo, Abeokuta, Nigeria
}

\section{Introduction}

Viral hepatitis is a life-threatening liver disease, caused by hepatitis B and C virus, and is a major public health problem, particularly in developing countries [1] [2]. The prevalence of HBV and HCV in a population can be predicted by risk factors associated with the transmission of infection such as injections, blood products transfusion, surgical procedures, body tattooing, occupational injury, sexual and vertical transmission [3]-[5]. Many infected individuals deny history of any of these risks so that the likely source remains unidentified in some subjects [6]. However, the prevalence varies from area to area and population to population due to variability in ethnicity and socioeconomic conditions [1] [2].

Viral hepatitis is the inflammation of the liver caused by infection with the hepatitis viruses; it can also be due to toxins (notably alcohol, certain medications and plants), other infections and autoimmune diseases [7]. Viral hepatitis during pregnancy is associated with high risk of maternal complications. Infections with the Hepatitis $\mathrm{B}$ virus (HBV) or the Hepatitis C virus (HCV) are public health problems and are highly endemic in the subSaharan Africa [8] [9]. Worldwide, there are about 350 million HBV carriers and 130 to 170 million people infected with HCV [10].

HBV and HCV infections are a major cause of morbidity and mortality. Hepatitis B virus has a circular genome of partially double-stranded DNA. The virus is transmitted through infected blood, sexually and vertically (mother to child) in the perinatal period. Perinatal transmission is the most common mode of HBV transmission worldwide [11]. The Hepatitis B surface antigen (HBsAg) is the serologic hallmark of HBV infection, whilst the soluble extractable protein, the Hepatitis e antigen (HBeAg) is a marker for the highly infectious state.

Communication is the key to the survival of any society. In home, lack of communication can result in total breakdown of marriage. It can lead to the collapse of an organization and even lead to anarchy in a society. Information is power; it gives knowledge and when people lack it, they perish. This is biblically corroborated, "my people perish for lack of knowledge”. The Quran also stressed that “... say: 'Are those equal, those who know and those who do not know? It is those who are endowed with understanding that receive admonition"” [12]. A good number of people have been reported dead for lack of information about certain diseases, especially, hepatitis. Communication of information is a big business that must be properly and professionally handled; especially, in a predominantly illiterate and largely rural population like ours in Nigeria.

If information is disseminated through inappropriate channels, no matter what the intensity and frequency are, it will be as bad as not communicating at all.

The mass media (radio, television, newspaper, etc.) are being engaged daily to disseminate information about certain life threatening diseases and the question has been-Is the impact adequately felt? Has it yielded the desired result? Are we giving the right information out at the right time?

For an item of communication to be effective, the channel and the timing must be appropriate. This has led to the focus of this study on the "Use of appropriate channels to discuss life threatening diseases".

It has been observed that government, organizations and even corporate bodies spend a lot of money to disseminate information about certain health problems that they consider epidemic while they have neglected some that are even more deadly and more contagious. Even when they disseminate information about such diseases, it is not with the intensity with which they discuss issues like Acquired Immune Deficiency Syndrome (AIDS), and very recently, Ebola Virus Disease (EVD). It has also been observed that when some of these more deadly and more contagious diseases are discussed, the channels that are used in most cases are not very appropriate.

Therefore, this study specifically examines hepatitis because it is a viral disease that kills more than the number being killed by AIDS; yet, not much is heard about it. The objective of this study is to examine the issues 
surrounding the dissemination of information about life threatening diseases, especially hepatitis with a view to helping health information experts determine the appropriateness of the medium or channels of communicating such health issues. It is also intended to call their attention to certain health problems that require aggressive campaigns that have hitherto been neglected.

\section{Research Method}

The research employed the survey method, using a combination of questionnaire, personal and telephone interviews. Personal interviews were used to elicit information from communication and health experts.

\section{Sample Size}

A sample size of 300 respondents was taken with the thinking that the population of Onikolobo, Abeokuta, Nigeria might not be more than 3000. The simple percentage unit of analysis was used for easy analysis (Tables 1-4).

\section{Results}

The study discovered that $60 \%$ of the total respondents do not know about hepatitis. $73 \%$ of those who claimed they knew about it knew through friends and not through the media. $80 \%$ of those who claimed they sought health information from the media do not know about hepatitis. $65 \%$ of those who claimed they had high access to radio did not really seek health information from the radio.

However, $75 \%$ of the total respondents considered radio as the best medium for disseminating health issues.

Table 1. Sex distribution of participants and their previous knowledge on hepatitis infection.

\begin{tabular}{cccc}
\hline Sex & $\begin{array}{c}\text { Total number of participant } \\
(\mathrm{n}) \text { and percentage }\end{array}$ & $\begin{array}{c}\text { Participants with prior knowledge on } \\
\text { hepatitis infection }\end{array}$ & $\begin{array}{c}\text { Participants without prior knowledge } \\
\text { on hepatitis infection }\end{array}$ \\
\hline Male & $109(36 \%)$ & $50(42 \%)$ & $78(43 \%)$ \\
Female & $191(64 \%)$ & $70(58 \%)$ & $102(57 \%)$ \\
Total & $300(100 \%)$ & $120(100)$ & $180(100 \%)$ \\
\hline
\end{tabular}

Table 2. Sources of information and participants' awareness.

\begin{tabular}{cccc}
\hline Sources of information & Positive response $n(\%)$ & Negative response, $n(\%)$ & Total \\
\hline Friends & $88(73 \%)$ & $32(27 \%)$ & $120(100 \%)$ \\
Media & $32(27 \%)$ & $88(73 \%)$ & $120(100 \%)$ \\
\hline
\end{tabular}

Table 3. Media channels of information dissemination on hepatitis.

\begin{tabular}{cccc}
\hline $\begin{array}{c}\text { Pattern of response to sources } \\
\text { of information dissemination }\end{array}$ & Radio, n (\%) & Television, n (\%) & Newspaper, n (\%) \\
\hline Respondent who say Yes & $90(75 \%)$ & $20(17 \%)$ & $10(08 \%)$ \\
Respondent who say No & $30(25 \%)$ & $100(83 \%)$ & $110(92)$ \\
Total, n (\%) & $120(100 \%)$ & $120(100)$ & $120(100)$ \\
\hline
\end{tabular}

Table 4. Other sources of information dissemination.

\begin{tabular}{|c|c|c|c|}
\hline $\begin{array}{l}\text { Pattern of response to other sources } \\
\text { of information dissemination }\end{array}$ & $\begin{array}{c}\text { Religious centres } \\
\text { (Mosques and Churches) } \\
\text { N (\%) }\end{array}$ & $\begin{array}{l}\text { Market place } \\
\text { N (\%) }\end{array}$ & $\begin{array}{l}\text { Other public for a } \\
\qquad \mathrm{N}(\%)\end{array}$ \\
\hline Yes & 85 (71\%) & $25(21 \%)$ & $10(09 \%)$ \\
\hline No & 35 (29\%) & 95 (79\%) & 110 (91\%) \\
\hline Total & 120 (100\%) & $120(100 \%)$ & 120 (100\%) \\
\hline
\end{tabular}


Only $20 \%$ said they were always sharing whatever health information they received on radio, television or newspapers with friends and associates.

Out of the total respondents, 98\% claimed they knew about Acquired Immune Deficiency Syndrome (AIDS) and Ebola Virus Disease (EVD) but only 40\% said they knew about hepatitis. The research also found that $50 \%$ of the educated respondents starting from Ordinary National Diploma (ND) certificate holders do not know anything about hepatitis.

The research also discovered that $45 \%$ of those who claimed they knew about hepatitis chose funny options. Some said it was a disease of the kidney while others said a disease of the bone, meaning they had little or no information about it. $70 \%$ of those who claimed to have heard about it did not know the symptoms while $60 \%$ of those who showed some level of knowledge of hepatitis did not even know how it is contracted, meaning that they did not even know how to prevent themselves from being infected.

The research also discovered that $90 \%$ of the respondents strongly agree that discussion on health problems should be taken to churches, mosques and other public for a by health officials.

\section{Discussion}

Infections due to Hepatitis B and Hepatitis C viruses (HBV, HCV) are significant health problems around the globe. Worldwide, viral hepatitis is the commonest cause of hepatic dysfunction in pregnancy. The prevalence of $\mathrm{HBV}$ varies between $2 \%$ in developed countries where the prevalence is low to about $8 \%$ in developing countries where infection is endemic with sex, age and socioeconomic status as important risk factors for infection [13]-[15]. Countries are classified as having low endemic rates $(<2 \%)$, intermediate endemic rates $(2 \%-8 \%)$, or high endemic rates (>8\%) positive for HBV.

Chronic infection is defined by the presence of HBsAg for more than 6 months. Without immunization, up to 90\% of infants born to mothers who are positive for HBsAg and HBeAg, become chronic carriers [16]-[18].

Hepatitis C virus is a single-stranded RNA virus, it is transmitted also through infected blood, sexually and vertically [19]-[21]. HCV has a long lag time between onset of infection and clinical manifestation of liver disease (up to 20 years) [22]. Chronic active hepatitis $C$ infection is associated with increased incidence of preterm delivery and intra-uterine growth retardation [23].

Vertical transmission of HCV from mother to child occurs in 3\% - 10\% of pregnancies complicated by HCV infection [24]. Among pregnant women, chronic infection with HBV and HCV are often asymptomatic, and can lead to coagulation defects, postpartum haemorrhage, organ failure and high maternal mortality and poor outcomes of their newborns such as still births, neonatal deaths (NND), jaundice, anorexia (poor appetite), malaise, acute and chronic liver disease (liver cirrhosis) and heap to cellular carcinoma. Maternal mortality has been shown to increase in pregnant women with liver cirrhosis [25].

In a study, the frequency of Hepatitis B and Hepatitis C infections among pregnant woman attending the Federal Medical Centre, Ido-Ekiti, Ekiti State Nigeria were $6.78 \%$ and $1.39 \%$ respectively while $0.15 \%$ was recorded for both HBV and HCVs co-infection. In another study, a prevalence of $6.78 \%$ and $1.39 \%$ was recorded for HBV and HCV respectively which was supported by World Health Organisation's (WHO) report for Nigeria, with prevalence of HBV and HCV greater than $8 \%$ and $1.2 \%$ respectively [26]. Other studies on prevalence of HBV done in Southeast Nigeria reported (2.2\%) [1], Obi reported (2.9\%) in the South-South Nigeria, Studies from the Middle East reported 4.3\% of HBV in Jordan [27] and 2.4\% in Saudi Arabia [28].

However studies from the Northeastern Nigeria by Olokoba reported (8.2\%), Ali reported 8.0\% seroprevalence of Hepatitis B in pregnant women; 8.3\% to 12.5\% was reported by other workers in Nigeria [13] [29].

The study discovered that $60 \%$ of the total respondents do not know about hepatitis. $73 \%$ of those who claimed they knew about it knew through friends and not through the media. 80\% of those who claimed they sought health information from the media do not know about hepatitis. 65\% of those who claimed they had high access to radio did not really seek health information from the radio. However, $75 \%$ of the total respondents considered radio as the best medium for disseminating health issues. Only $20 \%$ said they were always sharing whatever health information they received on radio, television or newspapers with friends and associates.

In this present study, out of the total respondents, 98\% claimed they knew about Acquired Immune Deficiency Syndrome (AIDS) and Ebola Virus Disease (EVD) but only 40\% said they knew about hepatitis. The research also found that $50 \%$ of the educated respondents starting from Ordinary National Diploma (ND) certificate holders do not know anything about hepatitis. 
Another study conducted in Abidjan, Ivory Coast, Africa show 8.5\% prevalence of HBV [30], 7.3\% prevalence of HBV among pregnant women in Kano as reported by Dawaki, also 5.6\% of HBV in Sudan was reported by Elsheikh et al., 2007 [31] among pregnant women. Further studies done among pregnant women in Addis Ababa (5.0\%), and Jimma, Ethiopia (1.4\% - 6.4\%) [32] [33]. Sierra Leone (6.2\%), Zambia (6.5\%), USA, only for Asian Americans (5.6\%), Jeju Island of Korea (4.9\% - 6.4\%), and Turkey (4.2\%) [34] [35]. In the North Central Mbaawuga reported (11.0\%) also 18.2\% was reported in Zaria by Luka et al., 2008.

Africa is considered to be a high prevalent zone for Hepatitis B, higher prevalence rates were reported from Ghana 10.5\% [36] and Yemen 13.2\% [37]. In United States, the prevalence of Hepatitis B and Hepatitis C is found to be $0.5 \%$ to $1.5 \%$ and $1 \%$ respectively [1].

The prevalence of HBV in this study shows an intermediate endemicity of HBV infection according to WHO criteria [38]. However, there are reports from other parts of the world showed a low prevalence in the same study population, a prevalence of $0.14 \%-0.97 \%$ in USA, except Asian Americans, in Mexico (1.65\%), in the northern part of Kerala state in South India (0.21\%), Qatar and the United Arab Emirates (1.0\% - 1.5\%) were reported [34] [39]. A higher prevalence was found among a similar study population in Mali (15.5\%), Hong Kong (China) (10.0\%), Papa New Guinea (11.0\%), Chinese Taipei (12.0\%), Oman (7.1\%) and in Brazil (18.5\%, ranging from 7.2\% - 38.5\%) [40] [41]. Comparison of our result with other studies from different countries on pregnant women showed a variable result. The difference in demographic characteristics of the study population such as socio-cultural environment, tribal practices, traditional operation, sexual practices, medical exposure and the difference in hepatitis epidemiology in these countries might explain these discrepancies.

It is hereby suggested that the media should do more in sensitizing the public about health issues, especially hepatitis. Since radio is used as a veritable tool by $75 \%$ of the respondents for disseminating information on health matters, let the media use the rate and frequency with which they give information on AIDS and EVD to discuss hepatitis because it is equally life threatening.

In the light of the discoveries of previous researches on health related issues cited in this paper and the basic postulates of the theories reviewed. It has become clear that mass media messages are meant to create awareness for a given health issue while interpersonal communication is meant to play a greater role at the adoption stage.

We have also seen that, for interpersonal communication to be effective, the relevant communication agents must be identified. Such relevant interpersonal communication agents are called opinion leaders: and that opinion leadership is conferred on an individual as a result of his political, religious, social economic and cultural attainments. It therefore means that an opinion leader could be the community head, club/association heads, pastors, imams or traditional heads and leaders and even family heads.

Vital health information could be communicated through such leaders or by health officials during church services or in the mosque. You will be surprised at the level of success of such messages.

It was very surprising that even the so called educated ones are not even aware of some serious health issues like Hepatitis, Cancer and even the need to have their blood pressure examined. For example, the first time one of the authors of this paper had his blood pressure examined was four years ago when his mother's death was attributed to high blood pressure. On examination, his pressure was found to be 150/100. This is just one of thousands of cases concerning the so-called elite. Such people can be reached through their professional bodies, clubs and association.

For media campaigns on health issues to be successful, health workers must be ready to enlist the support of these interpersonal communication agents because their words have a tone of finality on their people.

\section{Conclusions}

The fact that the mass media have been rated poorly in terms of the degree at which they have provided health information, especially about hepatitis means that media users do not get enough information on health issues until such issues become epidemic as in the case of Ebola Virus Disease (EVD). Most of those who get health information do not share with friends and colleagues and this means that health information does not always get to the grassroot. One wonders the rural dwellers' level of knowledge of this problem if a relatively informed community like Onikolobo, a suburb of Abeokuta, the Ogun state capital is not well informed about hepatitis.

Similarly, there should be increased public awareness, complete immunization against viral hepatitis, better sanitation facilities, safe drinking water, increased availability of antenatal care for early detection and well equipped hospitals for intensive care will go long way in the reduction of viral hepatitis in pregnancy and also its 
associated maternal and per-natal mortality and morbidity in the community.

\section{References}

[1] Santiago-Munoz, P., Roberts, S., Sheffield, J., McElwee, B. and Wendel Jr., G.D. (2005) 6.3\% Prevalence of Hepatitis B and C in Pregnant Women Who Are Infected with HIV. American Journal of Obstetrics and Gynecology, 193, 12701273. http://dx.doi.org/10.1016/j.ajog.2005.07.002

[2] Kumar, A., Sharma, K.A., Gupta, R.K., Kar, P. and Chakravarti, A. (2007) Prevalence and Risk Factors for Hepatitis C Virus among Pregnant Women. Indian Journal of Medical Research, 126, 211-215.

[3] Abildgaard, N. and Peterslund, N.A. (1991) Hepatitis C Virus Transmitted by Tattooing Needle. Lancet, 338, 460. http://dx.doi.org/10.1016/0140-6736(91)91095-C

[4] Akbar, N., Basuki, B., Mulyanto, Garabrant, D.H., Sulaiman, A. and Noer, H.M. (1997) Ethnicity, Socioeconomic Status, Transfusions and Risk of Hepatitis B and C Infection. Journal of Gastroenterology and Hepatology, 12, 752757. http://dx.doi.org/10.1111/j.1440-1746.1997.tb00365.X

[5] Luby, S.P., Qamruddin, K., Shah, A.A., Omair, A., Pahsa, O. and Khan, A.J. (1997) The Relationship between Therapeutic Injections and High Prevalence of Hepatitis C Infection in Hafizabad, Pakistan. Epidemiology and Infection, 119, 349-356. http://dx.doi.org/10.1017/S0950268897007899

[6] Roy, K.M., Goldberg, D., Taylor, A. and Mills, P. (2003) Investigating the Source of Hepatitis C Virus Infection among Individuals Whose Route of Infection Is Undefined: A Study of Ten Cases. Scandinavian Journal of Infectious Diseases, 35, 326-328. http://dx.doi.org/10.1080/00365540310008429

[7] Ahmedin, J., Taylor, M. and Ram, C.T. (2004) A New Section in Cancer Offering Timely and Targeted Information. Cancer Journal for Clinicians, 54, 23-25.

[8] Kwan, L.C., Cho, Y. and Lee, S.S. (1997) The Declining HBsAg Carriage Rate in Pregnant Women in Hong Kong. Epidemiology and Infection, 119, 281-283. http://dx.doi.org/10.1017/S0950268897007796

[9] Kramvis, A. and Kew, M. (2007) Epidemiology of Hepatitis B Virus in Africa, Its Genotypes and Clinical Associations of Genotypes. Hepatology Research, 37, 9-19. http://dx.doi.org/10.1111/j.1872-034X.2007.00098.X

[10] Goldstein, S.T., Zhou, F., Hadler, S.C., Bell, B.P., Mast, E.E. and Margolis, H.S. (2005) A Mathematical Model to Estimate Global Hepatitis B Disease Burden and Vaccination Impact. International Journal of Epidemiology, 34, 13291339. http://dx.doi.org/10.1093/ije/dyi206

[11] Tran, T.T. (2009) Understanding Cultural Barriers in Hepatitis B Virus Infection. Cleveland Clinic Journal of Medicine, 76, 10-13. http://dx.doi.org/10.3949/ccjm.76.s3.03

[12] The Holy Quran. Chap. 39, Verse 9, Translated by Al-Hilali, M.T. and Khan, M.M., King Fahd Complex for the Printing of Holy Quran, Saudi Arabia, 632 p.

[13] Ezegbudo, C.N., Agbonlahor, D.E., Nwobu, G.O., Igwe, C.U., Agba, M.I., Okpala, H.O. and Ikaraoha, C.I. (2004) The Seroprevalence of Hepatitis B Surface Antigen and Human Immunodeficiency Virus among Pregnant Women in Anambra State, Nigeria. Shiraz E-Medical Journal, 5, 1-25.

[14] Odusanya, O.O., Alufohai, F.E., Meurice, F.P., Wellens, R., Weil, J. and Ahonkhai, V.I. (2005) Prevalence of Hepatitis B Surface Antigen in Vaccinated Children and Controls in Rural Nigeria. International Journal of Infectious Diseases, 9, 139-143. http://dx.doi.org/10.1016/j.ijid.2004.06.009

[15] Alikor, E.A. and Erhabor, O.N. (2007) Seroprevalence of Hepatitis B Surface Antigenaemia in Children in a Tertiary Health Institution in the Niger Delta of Nigeria. Nigerian Journal of Medicine, 16, 250-251.

[16] McMahon, B.J., Alward, W.L.M., Hall, D.B., Heyward, W.L., Bender, T.R., Francis, D.P. and Maynard, J.E. (1985) Acute Hepatitis B Virus Infection: Relation of Age to the Clinical Expression of Disease and Subsequent Development of the Carrier State. The Journal of Infectious Diseases, 151, 599-603. http://dx.doi.org/10.1093/infdis/151.4.599

[17] Chang, M.H. (2000) Natural History of Hepatitis B Virus Infection in Children. Journal of Gastroenterology and Hepatology, 15, E16-E19. http://dx.doi.org/10.1046/j.1440-1746.2000.02096.x

[18] Sandesh, K., Varghese, T. and Harikumar, R. (2006) Prevalence of Hepatitis B and C in the Normal Population and High-Risk Groups in North Kerala. Tropical Gastroenterology, 27, 80-83.

[19] Dienstag, J.L. (1983) Non-A, Non-B Hepatitis I. Recognition, Epidemiology, and Clinical Features. Gastroenterology, 85, 439-462.

[20] Melbye, M., Biggar, R.J., Wantzin, P., Krogsgaard, K., Ebbesen, P. and Becker, N.G. (1990) Sexual Transmission of Hepatitis C Virus: Cohort Study (1981-9) among European Homosexual Men. BMJ, 301, 210-212. http://dx.doi.org/10.1136/bmj.301.6745.210

[21] Wejstal, R., Widell, A., Mansson, A., Hermodsson, S. and Norkrans, G. (1992) Mother-to-Infant Transmission of 
Hepatitis C Virus. Annals of Internal Medicine, 117, 887-890. http://dx.doi.org/10.7326/0003-4819-117-11-887

[22] National Institute of Health (2002) Management of Hepatitis C. NIH Consensus Development Program, 19, 1-35.

[23] Zanetti, A.R., Tanzi, E. and Newell, M.L. (1999) Mother-to-Infant Transmission of Hepatitis C Virus. Journal of Hepatology, 31, 96-100. http://dx.doi.org/10.1016/S0168-8278(99)80383-3

[24] Berkley, E.M.F., Leslie, K.K., Arora, S., Qualls, C. and Dunkelberg, J.C. (2008) Chronic Hepatitis C in Pregnancy. Obstetrics \& Gynecology, 112, 304-310. http://dx.doi.org/10.1097/AOG.0b013e318180a4f3

[25] Mishra, L. and Seeff, L.B. (1992) Viral Hepatitis, A though E, Complicating Pregnancy. Gastroenterology Clinics of North America, 21, 873-887.

[26] World Health Organization (1999) Global Surveillance and Control of Hepatitis C. Report of a WHO Consultation Organized in Collaboration with the Viral Hepatitis Prevention Board. Journal of Viral Hepatitis, 6, 35-47. World Health Organization (2011) Factsheet No. 164.

[27] Batayneh, N. and Bdour, S. (2002) Risk of Perinatal Transmission of Hepatitis B Virus in Jordan. Infectious Diseases in Obstetrics and Gynecology, 10, 127-132. http://dx.doi.org/10.1155/S1064744902000121

[28] Khalil, M.K.M., Al-Mazrou, Y.Y., Al-Jeffri, M., Al-Ghamdi, Y.S., Mishkhas, A., Bakhsh, M., Eisa, M., Nageeb, M. and Tumash, S. (2005) Seroprevalence of Hepatitis B Surface Antigen in Pregnant Saudi Women. Eastern Mediterranean Health Journal, 11, 640-647.

[29] Ugbebor, O., Aigbirior, M., Osazuwa, F., Enabudoso, E. and Zabayo, O. (2011) The Prevalence of Hepatitis B and C Viral Infections among Pregnant Women. North American Journal of Medical Sciences, 3, 238-241. http://dx.doi.org/10.4297/najms.2011.3238

[30] Sellati, M.P., Inwoley, A. and Claix, M.L. (2003) Prevalence of Hepatitis B/C Virus and HCV Genotypes in HIV Positive and Negative Women in Abidjan, Ivory Coast West Africa, 8, 974.

[31] Elsheikh, R.M., Daak, A.A., Elsheikh, M.A., Karsany, M.S. and Adam, I. (2007) Hepatitis B Virus and Hepatitis C Virus in Pregnant Sudanese Women. Virology Journal, 4, 104. http://dx.doi.org/10.1186/1743-422X-4-104

[32] Awole, M. and Gebre-Selassie, S. (2005) Seroprevalence of HBsAg and Its Risk Factors among Pregnant Women in Jimma, Southwest Ethiopia. Ethiopian Journal of Health Development, 19, 45-50.

[33] Tsega, E., Tsega, M., Mengesha, B., Nordenfelt, E., Hansson, B.-G. and Lindberg, J. (1988) Transmission of Hepatitis B Virus Infection in Ethiopia with Emphasis on the Importance of Vertical Transmission. International Journal of Epidemiology, 17, 874-879. http://dx.doi.org/10.1093/ije/17.4.874

[34] Euler, G.L., Wooten, K.G. and Baughman, A.L. (2003) Hepatitis B Surface Antigen Prevalence among Pregnant Women in Urban Areas: Implications for Testing, Reporting, and Preventing Perinatal Transmission. Pediatrics, 111, 1192-1197.

[35] Kang, H.S., Song, B.C. and Ji, C.X. (2004) Serologic Markers of Hepatitis B Virus in Pregnant Women in Jejuisland. The Korean Journal of Hepatology, 10, 191-196.

[36] Damale, N.K.R., Lassey, A.T. and Bekoe, V. (2005) Hepatitis B Virus Seroprevalence among Paturients in Accra, Ghana. International Journal of Gynecology and Obstetrics, 90, 240-241. http://dx.doi.org/10.1016/j.ijgo.2005.05.014

[37] Al-Shamahy, H.A. (2000) Prevalence of Hepatitis B Surface Antigen and Risk Factors of HBV Infection in a Sample of Healthy Mothers and Their Infants in Sana'a, Yemen. Annals of Saudi Medicine, 20, 464-467.

[38] WHO/EPI (1990) Protocol for Assessing Prevalence of Hepatitis B Infection in Antenatal Patients. WHO/EPI/ GEN/90.6.

[39] Al Awaidy, S., Abu-Elyazeed, R. and Al Hosani, H. (2006) Sero-Epidemilogy of Hepatitis B Infection in Pregnant Women in Oman, Qatar and the United Arab Emirates. Journal of Infection, 52, 202-206. http://dx.doi.org/10.1016/j.jinf.2005.05.006

[40] Clegg, T. (1991) Hepatitis B Surface and e Antigen Seropostivity in Mothers and Cord Blood at Port Moresby General Hospital: Implication for a Control Program. Papua and New Guinea Medical Journal, 34, 234-237.

[41] Sidibe, S., Sacko, B.Y. and Traore, I. (2001) Prevalence of Serologic Markers of the Hepatitis B Virus in Pregnant Women of Bamako, Mali. Bulletin de la Société de Pathologie Exotique, 94, 339-341. 